\title{
Entrepreneurial networking differences: An ethnic in-group and out-group analysis
}

Author:
Boris Urban'
Affiliation:
'Wits Business School,
University of Witwatersrand,
South Africa
Correspondence to:
Boris Urban
Email:
Boris.urban@wits.ac.za
Postal address:
PO Box 98, University
of Witwatersrand,
Johannesburg 2050,
South Africa
Dates:
Received: 07 Apr. 2009
Accepted: 01 Dec. 2010
Published: 05 Apr. 2011
How to cite this article:
Urban, B. (2011).
Entrepreneurial
networking differences:
An ethnic in-group and
out-group analysis. SA
Journal of Industrial
Psychology/SA Tydskrif
vir Bedryfsielkunde, $37(1)$,
doi:10.4102/sajip.v37i1.826

(C) 2011. The Authors. Licensee: OpenJournals Publishing. This work is licensed under the Creative Commons Attribution License.
Orientation: Researching entrepreneurship using a network perspective is important, as social networks are assets for small business owners struggling to survive in competitive markets.

Research purpose: The research question of this study has focused on what we can learn about entrepreneurial networking, considering that there is an under-explored and unarticulated set of networking principles and practices which have not been previously analysed in terms of a multiethnic country context.

Motivation for the study: Often the lack of network use is reported as a feature of entrepreneurs, who have less opportunity to utilise formal social capital features. Social networks provided by extended family, community-based or organisational relationships are often theorised to supplement the effects of education, experience and financial capital.

Research design, approach and method: Based on hypothesised differences in networking ties, network assistance and support relationships, a survey was used to collect data on quantitative measures. Descriptive statistics were calculated and differential tests were conducted to test the hypotheses.

Main findings: Results indicate that $\mathrm{s}$ of networking are generic and as a consequence, a more integrated view of networking can be adopted.

Practical/managerial implications: The practical value of the present study points to several areas of interest to entrepreneurs, policy makers and educators, through demonstrating the multifaceted nature of entrepreneurial networks for different groups and their explanatory potential in understanding networking.

Contribution/value-add: Despite the importance of entrepreneurial networking, little empirical or theoretical research has examined the dynamics of networking in a developing country context such as South Africa, which has lower than expected total entrepreneurship activity.

\section{Introduction}

The contemporary study of ethnic entrepreneurship and the importance of social embeddedness can be traced to the works of Max Weber and Joseph Schumpeter. Both argued that the source of entrepreneurship behaviour lay in the social structure of societies and the value structures they produce (Schumpeter, 1934; Weber, 1948). There is growing literature suggesting the importance of networks to entrepreneurs and even arguing that social capital may be the most significant source of knowledge for entrepreneurs (Arenius \& De Clercq, 2005; Audretsch \& Keilbach, 2004; Davidsson \& Honig, 2003). Entrepreneurial activity does not occur in a vacuum, but instead is rooted in cultural and social contexts, specifically within webs of personal and institutional networks (Chan, Bhargava \& Street, 2006). Entrepreneurship is embedded in networks of continuing social relations with studies indicating that networking allows entrepreneurs to enlarge their knowledge of opportunities, to gain access to critical resources, and to deal with business obstacles (Adler \& Kwon, 2002; Low \& MacMillan, 1988; McMillan \& Woodruff, 2002). Researching entrepreneurship using a network perspective is important, as social networks are crucial assets for small business owners struggling to survive in competitive markets (Aldrich \& Zimmer, 1986; Aldrich \& Waldinger, 1990; Audretsch \& Keilbach, 2004).

In South Africa, not only is there a sense of entitlement and an expectation that big businesses, government and others should create jobs, as opposed to one creating one's own employment, but 
aspiring entrepreneurs have low levels of entrepreneurial experience, inadequate education, and lack access to finance and business-orientated networks (Herrington, Kew \& Kew, 2010).

Entrepreneurs report on the lack of access to networks, highlighting the fact that these entrepreneurs have less opportunity to utilise formal social capital features (Menzies, Filion, Brenner \& Elgie, 2007). Social capital and social networks provided by extended family, communitybased or organisational relationships are often theorised to supplement the effects of education, experience and financial capital (Greve \& Salaff, 2003).

This study concentrates on networking because small firms are constrained by size to make sufficient investments in generating new knowledge; therefore it must engage in strategies to access knowledge essential for innovation by other means, such as networking. Despite the importance of entrepreneurial networking, a limited amount of empirical or theoretical research has examined the dynamics of networking in a developing country such as South Africa, where the total entrepreneurship activity (TEA) rates are lower than expected considering its per capita income (Orford, Herrington \& Wood, 2004).

Generally at least some aspects of business networking are generic and although a network developed by each entrepreneur is de facto unique to that individual, it is reasonable to postulate that given the socially-embedded nature of networking activities, entrepreneurs of different cultures may have different networking styles (Birley, Cromie \& Myers, 1991; Cooper \& Denner, 1998; Dodd \& Patra, 2002). Looking at networks in a multicultural context (such as South Africa) could provide a way of understanding what goes on within the relationships that make up a network and the extent to which patterns and relationships are common amongst people or unique amongst particular groups (De Klerk, 2010; Jack \& Anderson 2002; Jack, Dodd \& Anderson, 2008).

The rationale for studying networking from a group and ethnic perspective is that most studies investigating culture and entrepreneurship have used national affiliation, but the existing and increasing cultural diversity of many nations, especially in terms of South Africa's multiculturalism, render this strategy unsatisfactory (Foxcroft \& Roodt, 2001; Kruger \& Roodt, 2003; Lenartowicz \& Roth, 2001; Nkosi \& Roodt, 2004). In fact it has been suggested that if researchers include measures of ethnic identities of the samples they study, comparisons might be made with other studies that have more established theoretical roots (Bond \& Smith, 1996). In several studies, group characteristics have been invoked to help explain why some ethnic groups are disproportionately more evident in entrepreneurship (Menzies, Filion, Brenner \& Elgie, 2007). Such studies explicitly use the concept of insiders and outsiders to comprehend ethnic entrepreneurship (Jackson, 2002).
As a consequence, it is important to explore boundaries when examining cultural encounters, distinguishing one group from another, understanding language use, and determining inclusion or exclusion (i.e. who is considered part of the in-group or the out-group) is necessary because such determinants provide a basis for difference as well as real social, economic and political advantages and disadvantages (Flint, 2006).

This study builds on the emerging body of theory on entrepreneurship and networking and follows in the tradition of the series of global entrepreneurship monitor (GEM) studies, where business start-ups and activity in South Africa have been found to vary significantly by racial groups (Foxcroft, Wood, Kew, Herrington, \& Segal, 2002; Mass \& Herrington, 2007). GEM studies have consistently sampled participants according to five major languages spoken in South Africa and also describe entrepreneurial activity according to race classifications. Not only is there is reason to suspect that the nature of networking between ethnic or racial groups may differ but by identifying dominant categories of entrepreneurs, and linking them with research variables previously not related, will help elucidate how entrepreneurs react differently or similarly to each of the networking phenomena as specified for this article.

The research question of this study focuses on what we can learn about entrepreneurial networking, considering there is an under-explored and unarticulated set of networking principles and practices which have not been previously analysed in terms of a multi-ethnic country context.

In order to address the research question the primary objective of this article focuses on anticipated differences in networking practices between major racial groups in South Africa. Considering that the social network literature provides rich discussion of the concept 'embeddedness' (Granovetter, 1973, 1985), and recognises the importance of understanding group composition in order to understand social life (Simmel, 1955; Slotte-Kock \& Coviello, 2010), a secondary objective of this article is to highlight potential in-group and out-group attitudes of participants towards members involved in social exchanges.

The article starts with a brief contextualisation of entrepreneurship in South Africa, moves on to reviewing the literature on networking, and then unpacks the sub-cultural dimensions of ethnicity and race in order to establish the primary level of analysis. Hypotheses are formulated to reflect the study's objectives and statistical testing follows. The article ends where conclusions and recommendations are made in line with the study's empirical findings.

\section{Brief overview of entrepreneurial activity in South Africa}

South Africa has a dual-logic economy. On the one side, there is a highly developed economic sector and, on the other side, 
one finds an economic sector struggling for survival. Such entrenched inequalities act as a major determinant to growth, development, employment creation and poverty eradication, particularly when the schism between the poor and rich is widening (Lopez-Claros, Altinger, Blanke, Drezniek \& Mia, 2006; World Economic Forum, 2006). According to Statistics South Africa's labour force surveys, a total of 2.5 million small and medium enterprises (SMEs) are recorded, reflecting an annual increase rate of 6.5\% over the period 1994-2006 (Seda, 2007, p.18). The majority of these SMEs are owned by Black people; SMEs owned by women are currently not able to capitalise on opportunities in the broader economy. These SMEs tend to exist on the fringe of what has been labelled the 'first economy' (Seda, 2007; South Africa Survey, 2007). Although these small businesses serve a vital social function and assist in alleviating poverty, they do not provide much dynamism (La Porta \& Schleifer, 2008). Moreover, when measuring total entrepreneurship activity (TEA) rates, the GEM studies report that entrepreneurial activity not only varies significantly according to racial groups, but is lower than expected given its per capita income (Foxcroft et al., 2002; Orford et al., 2004).

In addition, in South Africa the convergence of risk from crime and security, corruption, and dysfunctional government poses challenges to entrepreneurship. These challenges seem to be further intensified by the fast receding non-racial utopia. Not only is the widening gap between poor Black people and the Black elite evident but the comfortable accommodation of an inclusive Black (i.e. the fragile bond of Coloured, Indian and African solidarity) is being fragmented. Advocating one nation with linked political and economic power further complicates this mosaic of ethnic and linguistic diversity (Jansen, 2004).

By actively considering these challenges to entrepreneurship, part of which includes stimulating entrepreneurial networking, the importance of addressing the low rates of entrepreneurial activity is recognised. Central to strategic actions initiated by the South African government, is the broadening of network support programmes and the streamlining of support institutions. These relate to the network structures facilitating, access to markets, access to finance and affordable business premises, the acquisition of skills and managerial expertise, access to appropriate technology, and access to quality business infrastructure in poor areas or poverty nodes (Seda, 2007). Although such interventions are important, networking and member relationships are nearly invisible to most scholars who study entrepreneurship and economic development in Africa; however, research is emerging which focuses on this phenomenon of entrepreneurship (Dodd \& Patra, 2002; McDade \& Spring, 2005).

\section{Previous research on entrepreneurial networking}

There are numerous studies focusing on networking as a key aspect of an entrepreneur's social capital base, which may be understood as the goodwill that is engendered by the fabric of social relations and that can be mobilised to facilitate action (Adler \& Kwon, 2002; Audretsch \& Keilbach, 2004; Granovetter, 1973). Two interrelated strands in African entrepreneurship are discussed by Naude and Havenga (2007). The first strand relates to industrial clusters and attempts to address the lack of cluster development in Africa. The second strand, which this article investigates, is concerned with entrepreneurial networks and the role of social capital in strengthening these networks.

From an entrepreneurial perspective, social capital provides networks that facilitate the discovery of opportunities, as well as the identification, collection and allocation of scarce resources and strategic initiatives (Davidsson \& Honig, 2003; Miller, Besser \& Malshe, 2007; Steensma, Marino \& Weaver, 2000).

Different types of networks have been identified in the research literature. For instance, by drawing on research from Ghana, innovation networks and solidarity networks are described as fulfilling different functions. Innovation networks improve firm performance by allowing better information flow between members, whilst solidarity networks are designed to reduce uncertainty (Naude \& Havenga, 2007, p. 37). Solidarity networks tend to dominate in Africa due to uncertainty, particularly in terms of a lack of contract discipline. Moreover, surviving or necessity entrepreneurs are reported as being more active in social relations than their unsuccessful counterparts (Sawyer, McGee \& Peterson, 2003).

\section{Networking practices}

Based on a synthesis of research investigating the nature of networking in small firms (Carson, Cromie, McGowan \& Hill, 1995; Curran, Jarvis, Blackburn \& Black, 1993), networking is described as an activity that varies according to the individual owner-manager and according to the person with whom the interaction takes place. Similarly, in a review of business networks, Blundel and Smith (2001) conclude that during venture creation, most entrepreneurs rely on informal sources in their personal networks in order to mobilise resources, especially before a venture is set up.

McDade and Spring (2005) describe how with donor funding assistance, entrepreneurs organised 31 national, three regional and one pan-African business network in West, East and Southern Africa. Since joining these networks some members are reported to be doing business with firms in other African countries with network members, but have not established linkages with traditional formal or informal sector small-scale entrepreneurs, which comprise most of the entrepreneurial landscape. Moreover, some members contend that there is more talking than actual business being transacted.

Nonetheless in spite of their poor social network infrastructure, African firms of varying size and structure 
make very effective use of business networks (AhwirengObeng, 2006). Empirical work, so far, has in fact provided evidence of some international similarities, as well as some national-level characteristics where entrepreneurial networking is concerned (Dodd, 1997; Dodd \& Patra, 2002). Such findings are instrumental in formulating the present study's hypotheses.

\section{Network diversity and ties}

Social capital is often operationalised through the identification of networks and network relationships, sometimes defined by the strength of ties, repetitive group activity such as the frequency of meetings and other formal interactions, as well as informal gatherings and other social activities, and social and family relationships. Street and Cameron (2007) report that characteristics of small business external relationships, such as relationship strength, network size, network structure, relationship type, goal compatibility and existing trust, represent the largest area of research regarding antecedents of relationships.

In order to formulate meaningful hypotheses, the analysis of network structure requires, firstly, attention to be paid to the quality of the constituent ties, that is, their frequency, intensity, multiplicity, and so forth, and to their configuration (Adler \& Kwon, 2002; McMillan \& Woodruff, 2002). The types of relationships that make up a person's total set of relations can be classified according to the strength of the relationship: strong, weak, and ties to strangers. A network's level of diversity depends, in part, upon the mix of strong and weak ties. Ties may be either direct or indirect, their intensity may vary, and the outcomes (in terms of bonding or bridging social capital) contingent on the type of network being analysed. Certain networking activities have been positively associated with firm performance, for instance, Aldrich and Zimmer (1986) report a positive relationship between firm survival and number of times per week of contact with network members.

In the context of entrepreneurial networks, people need access to information and other resources. The usefulness of any relation is context-dependent. Multiple diverse contacts are therefore important, regardless of their strength (Aldrich \& Carter, 2004, p. 325). This diversity in network ties is crucial for entrepreneurs, as diversity increases access to a wider circle of information about potential markets, new business locations, innovations, sources of capital, and potential investors. On the other hand, in homogeneous networks, information known to one person is rapidly diffused to others and interpreted in similar ways. Two forces promote homogeneity in personal networks: people tend to associate with others who have similar values and interests, and people tend to gravitate towards emotional and personal balance across their social relations (Adler \& Kwon, 2002).

\section{Network assistance, types of relationships and trust}

Networking assistance refers to the relationships and networks from which individuals are able to derive institutional support and allows them to act together more effectively to pursue shared objectives (Putnam, 1995).

Social exchange allows for a better understanding of the effects of exchange between different role players in a network relationship. Exchange effects may range from the provision of concrete resources (such as a loan provided by a mother to her daughter) to intangible resources such as information about the location of a new potential client (Aldrich \& Carter, 2004, p. 325). Welter and Smallbone (2006) find that successful new entrepreneurs are more likely to be those who can build networks of trust, which assist them in creating legitimacy within the market. A major factor enhancing the strength of social capital consists of trust, which is often a result of obligations, threat of censure and exchange. Networks which contain trust have been described as the 'glue and lubricant' which hold networks together (Davidsson \& Honig, 2003; Jack \& Anderson, 2002). This trust forms bonding glue that holds entrepreneurs together. Empirical results from a variety of Western and Eastern European economies illustrate that personal trust appears to play a less important role during periods of business growth and in stable (regional) environments, whereas institutional trust gains importance, although without dominating the nature and extent of entrepreneurship. By contrast, institutional trust needs personal trust to develop, regardless of the regional and sector environment. This implies that entrepreneurship is typically affected by a mixture of personal and institutional trust (Welter \& Smallbone, 2006), and is subsequently accounted for in formulating the hypotheses.

\section{Ethnic entrepreneurship}

Theoretical discourse on ethnic entrepreneurship includes research on the availability of capital resources, social performance, and race and gender issues (Aldrich \& Waldinger, 1990; Hackett, Betz, Casas \& Rocha-Sinjh, 1992). A common theme which pervades most ethnic entrepreneurship research is that ethnic groups adapt to the resources made available by their environments, with substantial variation across societies and time (Aldrich \& Waldinger, 1990; Chaganti \& Greene, 2002; Eghosa \& Osaghae, 2005).

Reviewing definitions in literature lead to three terms used most often in discussing ethnic entrepreneurs (Basu \& Altinay, 2002; Chaganti \& Greene, 2002; Ramachandran \& Shah, 1999):

- non-Caucasian entrepreneurs

- immigrant entrepreneurs

- minority entrepreneurs.

In this article it is argued that the way these definitions and most western discourse on ethnic entrepreneurship is categorised, has little relevance for studying a multi-ethnic society (such as South Africa) where such categorisations do not reflect realistic ethnic and racial distributions amongst the population. The concept of ethnic minority does not seem to fit the complex heterogeneous nature of South 
African society. Indeed, contrasting most ethnic minority studies (unlike in most developed countries) in South Africa, no policies impede ethnic business development. Empowerment is not only widely advocated by the South African government but also legislated in terms of strategy designed by government to introduce Black, Coloured and Asian citizens into the business landscape without disrupting the economy (South Africa Business Guidebook, 2005/2006).

\section{Ethnic and racial categorisations}

There appears to be a general malaise regarding newer studies on race and racism in South Africa at present, even though race has been central to South African history for the past 350 years and is certainly pivotal to social transformation (Stevens, 2003). During the apartheid era, South African society was legally divided into four population groups, namely (Bureau of Market Research, 2001):

- Black African people

- White people

- Coloured people

- Asian or Indian people (used interchangeably in this article).

This division continues to be used in the discourses of policy, the media and daily conversation. The terminology of the racial categories is still used in official statistics published by Statistics South Africa (SSA) and has been maintained by the post-democracy government for the purposes of promoting employment equity and equal opportunity (Carmichael \& Rijamampianina, 2006).

It is acknowledged that the term race used to divide people into discrete reified social categories (Duncan, 2003) could well be considered prejudicial, but in South Africa has been used in the past and even today to justify extant patterns of domination, exclusion and entitlement. As a consequence, this racial indicator is important and therefore needs to be accounted for in a study on ethnicity and entrepreneurship. Following this, the focus in this article is on ethnicity as an element of culture, which in turn has largely been shaped by race in South Africa. In line with Stephan and Stephan's (2000) argument where even though anthropology groups advocate elimination of race categories, such measurements are here to stay as a number of purposes are served by racial or ethnic identification. Specifically, a variety of country-specific data needs are served by this classification. Race is also an important social concept; people use these classification systems in everyday life, even though researchers and activists would prefer that they did not. Because they are widely applied to the self and to others, social scientists have an obligation to understand these classification systems and the effects of their usage.

Further considerations when employing the various racial groups are that deep-seated differences occur between these groups which can be ascribed to divergent cultural, language and religious factors together with historical experiences (Bornman, 1999, 2006). Both racial and ethnic identity have been found to vary according to respondents' language orientation a phenomenon which reflects the ethno-cultural background of a particular group (Franchia \& Swart, 2003). Particularly relevant to this article is that Africa's ethnolinguistic fragmentation is a factor that might undermine networks (Naude \& Havenga, 2007).

\section{In-group and out-group membership}

An important attribute of ethnicity is that it is a principle of social cohesion and organisation. Studies wherein individuals have been allowed to self identify their ethnicity, have demonstrated that racial and ethnic identity is neither an objective nor stable feature of social life (Stephan \& Stephan, 2000). Rather, racial and ethnic identity is dependent upon both the individual's identity and others' identification of the individual and ethnic identities are ascribed by others and avowed by the self. It is for this reason that an in-group and outgroup analysis is proposed, particularly as a number of social and political interests may be better served by identifying with one group rather than another. The size, visibility and status of the group are obvious factors that influence the role of ethnicity in the social, political and economic realms (Gong, 2007; Stephan \& Stephan, 2000). Ethnic associations are particularly important for entrepreneurship because they not only express differences but also perform the judicial function of settling disputes involving members of the in-group and out-group; they centre round the interests of members of the association and the ethnic community, and include guarantees of social security and protection to members of the in-group and offer connections to job-seekers and workers in places of employment (Bhowon \& TseungWong, 2003; Jackson, 2002; Watson \& Kumar, 1992).

Social identity theory is used to explain the way people integrate membership of social groups as the social component of their self concepts, with a positive or negative self concept defined by the status of people's membership groups in relation to relevant other groups (out-groups) in society. When investigating factors influencing ethnic identity in South Africa, personal, social, economic, and political factors have all been found to be relevant to ethnic identification and self-image. Despite the multidimensional nature of these identities, inter-group behaviour is usually driven by social identities and these are typically evaluated in a particular inter-group context (Aldrich \& Waldinger, 1990; Bhowon \& Tseung-Wong, 2003; Chaganti \& Greene, 2002; Hackett $e$ t al., 1992). Understanding how ethnic identity can contribute to national identity is important since the identification with the majority group and national identity is empirically different concepts (Gong, 2007), One cannot sustain an identity as a member of a group in the absence of knowledge regarding the group (Stephan \& Stephan, 2000). Past studies have explicitly used the concept of insiders and outsiders to comprehend ethnicity (Jackson, 2002). Individuals perceive others based on social category membership, designating some as in-group members ('like $\mathrm{me}^{\prime}$ ), and others as outgroup members ('not like me') (Griffiths \& Nesdale, 2006). Recognising the importance of using insiders and outsiders 
to comprehend ethnicity, and in line with the secondary aim of this research which was to better understand social category membership, participants were provided with the opportunity to indicate their attitudes toward in-group members, as well as out-group members.

\section{Hypotheses rationale and formulation}

Recognising and highlighting the importance of networking to entrepreneurs, whilst merging the literature on ethnicity or race and networking, it is postulated that entrepreneurial networking practices differ between ethnic or racial groups. Because ethnicity reinforces some personal characteristics and penalises others, one could expect some groups to practice networking differently than others, particularly as these groups have largely been shaped by race in South Africa. Such differences are also reflected in the variation reported in entrepreneurial activity in South Africa in the series of GEM reports (Foxcroft et al., 2002). Recognising the context in which South African entrepreneurs operate under, and building on the theoretical streams of ethnicity and networking, not only is there reason to suspect that the nature of networking between racial groups may differ but by identifying these groups with research variables previously not related to, will help elucidate how entrepreneurs react differently or similarly to networking phenomena (as specified for this article). In addition, as past studies have explicitly used the concept of insiders and outsiders to comprehend ethnicity (Jackson, 2002), this article also explores inclusion or exclusion in terms of an in-group and out-group analysis. Moreover, the use of language orientation as a dimension along which to compare subsamples in this study will further help explain tendencies towards in-groups and out-groups in terms of socio-cultural differences. Hypotheses of the present study include:

- Hypothesis 1: Significant differences exist between Black and Indian and White groups on network ties.

- Hypothesis 2: Significant differences exist between Black and Indian and White groups on network assistance.

- Hypothesis 3: Significant differences exist between Black and Indian and White groups on network support relationships.

- Hypothesis 4: Significant differences exist between Black and Indian and White groups in attitudes towards ingroup and out-group members.

- Hypothesis 5: Significant differences exist between ingroup and out-group members in terms of language.

\section{Research design}

\section{Research approach}

The research design was cross-sectional and a quantitative based approach was used to survey networking principles within an ethnic group analysis. This stance is supported in previous investigations of similar studies in networking (Aldrich \& Waldinger, 1990). It is further argued that applying formal measurement and statistical analysis to multiple variables cannot truly be deemed to be a positivistic philosophy, as nothing in the nature of this data will prevent deeper speculations and insights from emerging when analysed (Davidsson, 2004).

Apart from the respondents' biographic details, the survey measured in-group and out-group tendencies. Data was collected on several networking activities and sought a number as an answer (e.g. a number of meetings per week or hours expected), therefore responses were solicited in a manner to allow for quantitative analysis and most items were measured with either categorical, ratio or interval (1-5 Likert) scales.

\section{Research method \\ Sampling and data collection}

Setting the sample size for this study was based on anticipating subgroup analyses. Although the size of sample was not to be the focal point of this article, Hofstede (1991) maintains that a quota control on cultural or ethnic groups is necessary in order to ensure that a minimum sample size of at least $20-50$ is achieved for each of these subgroups. Respondents of the study comprised 77 Black South African entrepreneurs, 34 Indian South African entrepreneurs, and 56 White South African entrepreneurs.

A generic sampling frame was identified from membership lists of businesses operating in the greater Johannesburg area and included:

- business referral and information network (BRAIN)

- department of trade and industry (DTI)

- Johannesburg chamber of commerce and industry (JCCI).

The population of these databases consists of approximately 4600 firms. A nonprobability sampling approach was used to gather data from respondents. A total of 367 respondents were initially surveyed in 2008 who met the screening criteria of owning and managing a running business that has paid salaries, wages or any other payments to the owners for more than 3 months (Autio, 2007). A wide range of businesses were sampled which included typical businesses prevalent in the SME sector, for instance, agriculture, small-scale manufacturing, construction, financial, business, retail, motor trade and repair services, catering, accommodation and other trades, transport, storage and communications businesses. The trading environment was characterised by both formal and informal premises, and some of these included an office, street trader or hawker, craft market, home or friend's home, container or caravan, or local shopping centre. All entrepreneurs were based in the Gauteng province, the economic hub of South Africa, which has the highest number of both formal and informal entrepreneurs (SA Business Guidebook, 2005/2006). Based on eligibility criteria and suitability of respondents, 180 usable responses (an effective $49 \%$ response rate) were generated as the final sample.

\section{Measuring instruments}

The first section of the questionnaire was concerned with the respondents' biographical data which included questions relating to home language and race or ethnicity categories. 
The second section of the questionnaire focused on networking principles. In order to allow for meaningful comparisons with earlier work, a core set of questions based on the panel study of entrepreneurial dynamics (PSED) (Gartner, Shaver, Carter \& Reynolds, 2004) survey were selected. The PSED provides systematic, valid, reliable data on those variables that explain and predict nascent entrepreneurship. The proposed measures in this section have been previously subjected to factor analysis, with satisfactory results achieved in terms of factor loadings and reliability (Cronbach's Alpha of 0.64) across country samples, including developing countries such as Malaysia, India and Korea (Carter, Reynolds \& Gartner, 2004).

The first part (A) of the questionnaire was concerned with network diversity and ties which focused on the number of persons who had been helpful to the respondent with the start-up process (Aldrich \& Carter, 2004). The questions sought to answer how strong is the tie between the respondent and each of the helpers? These questions required a number as an answer (e.g. of meetings per week, or hours expected). Questions included 'How long have you known each helper' and 'How many times have you talked with each helper about business matters in the last week?'

For part B of the questionnaire, respondents would describe his or her relationship in terms of network support which was based on a list of role relationships. Items were assessed on 5-point Likert scale ranging from 1 ('very good') to 5 ('very poor'). The list included spouse or partner, family member or relative, a business associate or work colleague, a friend or acquaintance, a teacher or counsellor, and whether or not respondents have other types of relationships. Items produced an overall satisfactory Cronbach's Alpha of 0.71 across total items.

The next section considers in what way each helper has contributed to the start-up effort and on what terms. Here respondents were asked which forms of assistance had been most important for the new business start-up from each helper and included:

- introductions to other people, information or advice, training in business-related tasks or skills, access to financial resources (equity, loans or loan guarantees)

- physical resources (use of land, space, buildings or equipment)

- business services (legal, accounting and clerical assistance)

- personal service (household help)

- other kinds of assistance, moral or emotional support, labour, creativity or ideas.

To capture the second part of this question (i.e. on what terms were the help provided), questions focused on whether the assistance was provided:

- free of charge (1)

- at a discounted price (2)

- at the normal market price (3)

- as part of a barter or exchange relationship (4)

- for some other reason (5).
Based on the variety of items surveyed, this scale provides both an absolute measure of importance and a relative measure (ranking) of the various items rated.

The last section of the questionnaire was concerned with a series of questions pertaining to in-group and out-group membership that was based on major South African ethnic or race group categories. Various scales based on social identity theory which emphasises loyalty, commitment, pride and respect for the in-group were interrogated. In the final analysis, based on a pre-established instrument, eight items were used to assess feelings, thoughts and behavioural tendencies toward the in-group and out-group (Jackson, 2002; Jackson \& Smith, 1999). This bidimensional scale has been subjected previously to factor analysis, with satisfactory results obtained in terms of factor loadings (2-factors solution) and reliability (Cronbach's Alpha of 0.77 and 0.87 respectively). Generally a value above 0.70 is considered adequate for internal consistency (Nunnally, 1978).

Four questions assessed in-group tendencies, such as 'Members of the in-group are honest' and four questions assessed out-group tendencies, such as 'I like to go to a party consisting mostly of out-group members'. Items were assessed on 5-point Likert scale ranging from 1 ('strongly agree') to 5 ('strongly disagree'). No items were negatively worded and participants were asked to select an in-group (a group you belong to which forms part of your identify), restricted to one of the racial groups provided with the same selection being used for the out-group ('Select which groups you do not belong to').

An interitem correlation matrix was calculated for items in this scale indicating positive but relatively low intercorrelations between items. With short scales (less than 10 items), it is appropriate to report the mean interitem correlation for the items (Pallant, 2007). Moreover, the internal consistency of each construct was also evidenced by the face validity or conceptual relatedness of the items. This relatedness may be attributed to the theoretical grounding of the scales that were developed for the original study.

\section{Research procedure}

The survey was solicited physically and electronically with periodic reminder telephone calls. Permission was obtained from the individuals to voluntarily undertake the survey and ethical clearance to contact database members was established with the participating institutions.

\section{Analysis of data}

Apart from the reliabilities already reported in the measurement section, descriptive statistics were calculated and the resultant output was split by ethnic group which entailed conducting crosstabs on the categorical variables. Frequencies and percentages were calculated on individual items at the ratio level for characteristics and differences in networking principles between ethnic groups. Means and standard deviations were calculated for the interval scales. 
Following prior methods used to detect significant differences in entrepreneurial networking (Chan, Bhargava \& Street, 2006), and based on data type, the hypothesised differences across variables were tested using various inferential statistics. Overall Chi-square differences were calculated on ratio level data across groups, and on the interval scales differences were calculated on individual items using both parametric and non-parametric tests.

\section{Results}

Results based on the respondents' biographic details, revealed the following, for the total sample:

- mean age (33 years)

- gender $($ male $=53 \%$; female $=47 \%)$

- race group composition $($ Black $=43 \%$; Asian $=19 \%$; White $=31 \%$; Coloured $=7 \%$ ).

Only Black, Asian and White groups were further analysed as the Coloured group had negligible counts. A profile of respondents and networking ties, per group of entrepreneurs is shown in Table 1. No significant differences were detected on demographic variables for the different groups. In additionally, the number of people identified as helpful in networking comprised 1-2 people, with no significant differences between the groups (not shown). Research on entrepreneurial networking has found that most business owners name no more than three helpers, resonating with the present study.

Hypothesis 1 was tested in terms of networking ties, which measured length of relationship and frequency of contact, that is, by asking how many times the respondents had talked with helpers about business matters in the past month. Considering the ratio nature of the data, the helpers' responses were consolidated and averaged as reflected per group (Table 1). Significant differences were detected across all three groups only for one aspect of network ties, that is, frequency of contact (Table 1):
- Black respondents $=\left(\chi^{2}=11.083 ; d f=3 ; p=0.011\right)$

- Asian respondents $=\left(\chi^{2}=13.647 ; d f=3 ; p=0.003\right)$

- White respondents $=\left(\chi^{2}=12.399 ; d f=3 ; p=0.006\right)$.

The results obtained here provide partial support for Hypotheses 1, with significant differences detected only for frequency of contact between groups. These results indicate that variation exists in terms of how groups use networking ties.

Results in terms of network assistance, where respondents were asked to rank the different forms of assistance rendered by each helper are displayed in Table 2. The number of people recorded as helpful in networking was an average of two people for all three groups. Varied types of assistance are reported across groups, where 'introductions to other people' reflect the highest percentage (32\%) for helper 1 for the Black group and 'training in business skills' reflects the highest percentage (23\%) for helper 2 for the Black group. The lowest ranked types of assistance provided by helpers, were personal services and labour for both helper 1 and 2 for the Black group. Similar percentage readings can be interpreted for the Asian and White groups.

Testing Hypothesis 2, significant differences are detected for the Black group only $\left(\chi^{2}=18.758 ; d f=9 ; p=0.027\right)$. As a consequence, partial support is found for Hypothesis 2, where it was hypothesised that differences exist between Black, Indian and White groups on network assistance. In terms of how assistance was provided, all groups reported that it was mostly provided for free, with no significant differences detected between groups (not shown).

In Table 3 each respondent described his or her network support relationship from a list of role relationships. This question can be taken to indicate diversity in the kinds of role relationships a respondent has with various role players. Based on interval scales, mean scores and standard deviations were calculated. Relatively high mean scores are apparent

TABLE 1: Characteristics and differences in networking relationships and ties between ethnic groups.

\begin{tabular}{|c|c|c|c|c|c|c|c|c|c|c|c|c|}
\hline \multirow[b]{2}{*}{ Variables } & \multicolumn{3}{|c|}{ Ethnic groups } & \multicolumn{3}{|c|}{ SD } & \multicolumn{3}{|c|}{$\chi^{2}$} & \multicolumn{3}{|c|}{ Sig. ( $p$-Value) } \\
\hline & B & A & w & B & A & $\mathbf{w}$ & B & A & w & B & A & w \\
\hline Gender & - & - & - & - & - & - & 1.739 & 0.841 & 0.402 & 0.187 & 0.477 & 0.526 \\
\hline Male & 68 & 61 & 53 & - & - & - & - & - & - & - & - & - \\
\hline Female & 32 & 39 & 48 & - & - & - & - & - & - & - & - & - \\
\hline Age in mean years & 34 & 36 & 32 & 10.8 & 9.7 & 11.01 & - & - & - & - & - & - \\
\hline Networking ties & - & - & - & - & - & - & 4.417 & 7.377 & 0.620 & 0.220 & 0.061 & 0.892 \\
\hline Less than 1 year & 11 & 10 & 14 & - & - & - & - & - & - & - & - & - \\
\hline $2-4$ years & 32 & 33 & 32 & - & - & - & - & - & - & - & - & - \\
\hline $5-7$ years & 24 & 29 & 27 & - & - & - & - & - & - & - & - & - \\
\hline 8 years or more & 33 & 29 & 27 & - & - & - & - & - & - & - & - & - \\
\hline Number of times talked ... last week & & & & - & - & - & 11.083 & 13.647 & 12.399 & $0.011 *$ & $0.003 * * *$ & $0.006 * *$ \\
\hline Once or less & 11 & 17 & 10 & - & - & - & - & - & - & - & - & - \\
\hline 2-5 times & 39 & 29 & 28 & - & - & - & - & - & - & - & - & - \\
\hline 6-9 times & 19 & 28 & 22 & - & - & - & - & - & - & - & - & - \\
\hline 10 times or more & 31 & 26 & 39 & - & - & - & - & - & - & - & - & - \\
\hline
\end{tabular}

SD, Standard Deviation; Sig., Significance; $p$, probality value; B, Black ethnic group; A, Asian ethnic group; W, White ethnic group.

SD, Standard Deviation; Sig., Significance;
Ethnic group results are measured in $\%$.

${ }^{*}, p<0.05$ (two-tailed); ${ }^{* *}, p<0.01$ (two-tailed); ${ }^{* *}, p<0.005$ (two-tailed), indicates statistical difference. 
TABLE 2: Types of networking assistance provided, by persentage, by each helper for different ethnic groups.

\begin{tabular}{|c|c|c|c|c|}
\hline Type of assistance & Helper & Black & Asian & White \\
\hline \multirow[t]{2}{*}{ Introductions to other people } & 1 & 32 & 18 & 19 \\
\hline & 2 & 12 & 16 & 23 \\
\hline \multirow[t]{2}{*}{ Information or advice } & 1 & 18 & 25 & 19 \\
\hline & 2 & 22 & 23 & 16 \\
\hline \multirow[t]{2}{*}{ Training in business skills } & 1 & 15 & 16 & 12 \\
\hline & 2 & 23 & 14 & 11 \\
\hline \multirow[t]{2}{*}{ Access to financial resources } & 1 & 15 & 11 & 5 \\
\hline & 2 & 14 & 9 & 9 \\
\hline \multirow[t]{2}{*}{ Physical resources } & 1 & 7 & 9 & 5 \\
\hline & 2 & 11 & 13 & 10 \\
\hline \multirow[t]{2}{*}{ Business services } & 1 & 4 & 4 & 13 \\
\hline & 2 & 2 & 6 & 10 \\
\hline \multirow[t]{2}{*}{ Personal services (household help) } & 1 & 2 & 6 & 4 \\
\hline & 2 & 1 & 4 & 2 \\
\hline \multirow[t]{2}{*}{ Moral or emotional support } & 1 & 4 & 4 & 7 \\
\hline & 2 & 3 & 7 & 5 \\
\hline \multirow[t]{2}{*}{ Labour } & 1 & 2 & 4 & 5 \\
\hline & 2 & 2 & 1 & 2 \\
\hline \multirow[t]{2}{*}{ Creativity or ideas } & 1 & 3 & 8 & 10 \\
\hline & 2 & 11 & 6 & 13 \\
\hline Overall chi-square differences & - & 18.758* & 5.23 & 6.54 \\
\hline $\begin{array}{l}\text { Statistical significant difference for } \\
\text { helpers }\end{array}$ & - & 0.027 & 0.814 & 0.685 \\
\hline
\end{tabular}

TABLE 3: Statistics for networking support relationship between ethnic groups.

\begin{tabular}{|c|c|c|c|c|c|c|c|c|}
\hline \multirow[t]{2}{*}{ Role player } & \multicolumn{2}{|c|}{ Black } & \multicolumn{2}{|c|}{ Asian } & \multicolumn{2}{|c|}{ White } & \multirow{2}{*}{$Z$-score } & \multirow{2}{*}{$\begin{array}{c}\text { Sig. } \\
\text { (p-value) }\end{array}$} \\
\hline & $M$ & SD & $M$ & SD & $M$ & SD & & \\
\hline $\begin{array}{l}\text { Spouse or } \\
\text { partner }\end{array}$ & 3.42 & 0.70 & 3.23 & 0.57 & 3.98 & 0.87 & -1.437 & 0.114 \\
\hline $\begin{array}{l}\text { Family or } \\
\text { relative }\end{array}$ & 3.23 & 0.68 & 4.11 & 0.77 & 3.96 & 0.43 & -1.121 & 0.244 \\
\hline $\begin{array}{l}\text { Business } \\
\text { associate }\end{array}$ & 3.31 & 0.79 & 3.34 & 0.75 & 3.45 & 0.71 & -0.987 & 0.664 \\
\hline $\begin{array}{l}\text { Friend or } \\
\text { acquaintance }\end{array}$ & 3.21 & 0.76 & 3.78 & 0.56 & 3.43 & 0.53 & -1.145 & 0.229 \\
\hline $\begin{array}{l}\text { Teacher or } \\
\text { counsellor }\end{array}$ & 2.93 & 0.63 & 2.55 & 0.54 & 3.01 & 0.66 & -1.977 & 0.355 \\
\hline Other & 3.45 & 0.77 & 3.76 & 0.75 & 3.44 & 0.55 & -0.923 & 0.651 \\
\hline
\end{tabular}

relationship

Kolmogorov-Smirnov and Shapiro-Wilk test scores indicate that normality was violated. Subsequently Mann-Whitney $\mathrm{U}$ and Wilcoxon $\mathrm{W}$ test statistics rendered overall nonsignificant Z-scores.

$M$, Mean; SD, Standard Deviation; Sig., Significance; $p$, Probability.

for various role players across groups. In the Black group most assistance took the form of spouse or partner $(M=3.42$, $\mathrm{SD}=0.70)$, for the Asian group it was family or friends $(M=4.11, \mathrm{SD}=0.77)$, and the White group took the form of spouse or partner $(M=3.98, \mathrm{SD}=0.87)$. These scores may be interpreted as indicating a relatively medium range of diversity in the kinds of role relationships that these respondents have with different helpers.

In order to test Hypothesis 3 by applying tests of normality and calculating the Kolmogorov-Smirnov and Shapiro-Wilk statistics, test scores indicated that normality was violated. Subsequent to this, to test for differences between the groups on network support relationships, non-parametric tests were used. Both the Mann-Whitney $U$ and Wilcoxon
$\mathrm{W}$ test statistics rendered nonsignificant $\mathrm{Z}$ scores, meaning no support can be found for Hypothesis 3. These results reveal that differences between groups are not statistically significant when it comes to network support relationships provided by different role players.

Descriptives for the in-group and out-group items were calculated (Table 4). Most mean scores are relatively midpoint, suggesting that respondents neither strongly agree nor strongly disagree with statements measuring attitudes towards in and out-groups. For the Black group, several items indicate some disagreement with statements describing the out-group category, for instance, the item 'I like to go to a party consisting mostly of out-group members' $(M=3.36, \mathrm{SD}=1.08)$, and 'members of the out-group are honest' $(M=3.14, \mathrm{SD}=0.94)$. However, for the in-group, mean scores show greater tendency towards agreement rather than disagreement; for instance, the item 'I like members of the in-group' $(M=2.08, \mathrm{SD}=0.97)$.

In contrast, for the Asian group mean scores are higher for the in-group, suggesting some disagreement with statements measuring attitudes, especially for the item 'I like members of the in-group' $(M=3.87, \mathrm{SD}=0.54)$. For the White group, the highest mean scores indicating disagreement are for the in-group 'I like members of the in-group' $(M=3.99$, $\mathrm{SD}=0.43)$.

To test Hypothesis 4 (which relates to differences in group attitudes for the in-group and out-group, and is not linked to networking practices) a one-way analysis of variance (ANOVA) was used to detect differences between groups. ANOVA calculated $F$-ratios with only two significant scores detected, that is, for the item 'members of the out-group are honest', $F=3.62, p=0.02$, and for the item 'members of the in-group are decent' $F=3.40, p=0.03$. Considering that significant differences are detected on only two items relating to in-group and out-group tendencies, support for Hypothesis 4 is restricted.

Based on these results it was decided to test for practical significance, where the groups were compared across the same variables pertaining to attitudes towards the in-group and out-group. In this instance, Cohen's $d$ is calculated, where no large effects could be detected from the results in Table 4. Cohen (1988) defined effect sizes as small $(d=0.2)$, medium $(d=0.5)$ and large $(d=0.8)$. Therefore data with $d \geq 0.8$ is considered as practically significant, as it is the result of a difference having a large effect. Therefore only partial and very modest support is found for Hypothesis 4 .

In order to make further sense of the results, items which assessed behavioural tendencies toward the in-group and out-group were again split by group. However, the focus was not on racioethnic differences this time, but on sociocultural differences (primary language). 
Major South African languages were surveyed, which included Sotho, English, Zulu, Xhosa, Afrikaans, and a category labelled other. Comparisons between language groups in terms of in-group and out-group analysis were conducted. Descriptive statistics for the various languages were calculated initially and then compared. Comparisons were made using Levene test statistics. Testing for homogeneity of variances resulted in satisfactory nonsignificant results. As a subsequence, parametric tests were used (refer to ANOVA results in Table 5). The dependant variables (DV) are the summed items on in-groups (1) and out-groups (2). This table was interpreted as follows: for ingroup there is a 0.808 probability of obtaining an $F$-value of 0.457 or higher if there are no differences amongst group means in the population. As this probability exceeds 0.05 one can conclude that there are no significant differences amongst the mean scores on this DV for the various languages. However, for the second DV (out-group) a significant value was observed $(p=0.002)$. To determine where the differences amongst the groups occur, post-hoc multiple comparison tests were calculated such as the Scheffe and Dunnett T3 tests. Tables 6 and 7 provide the results on the homogeneous subsets for each DV. The combined results in these tables indicate that there were no significant differences on scores across languages for this in-group and out-group analysis; therefore Hypothesis 5 cannot be accepted.

\section{Discussion}

Building on previous research focusing on networks as an instrument for investigating the creation and development of new ventures (Slotte-Kock \& Coviello, 2010), and given the socially-embedded nature of networking, it was expected that entrepreneurs from different ethnic or racial groups may display different networking activities.

The empirical findings indicate few differences between groups on networking practices, suggesting little variation in how entrepreneurs network in terms of network ties, support by helpers and relationships. These findings, albeit modest, are encouraging for a relatively new field where many issues remain unresolved, and where networking practices have not been previously linked with ethnicity or race.

Based on the study's primary objective of trying to determine if differences exist on how groups use and draw on networks, only partial support was found for some of the hypotheses. In terms of Hypothesis 1, anticipating differences between Black, Indian and White groups on network ties, significant differences were detected only in frequency of contact between the groups. These findings are pertinent because of the relatively strong commitment and likely reciprocal relations to occur between two people who have accrued a certain length of time in a relationship. Strong-ties, following Granovetter (1973), are defined as those with whom the entrepreneur interacts at least twice a week. Weak-ties are relationships that are enacted less than twice a week, but at least once a year. However, the most reliable relationships in a personal network are strong-ties, which are usually of long duration; they are long-term, two-way relationships, not governed by short-term calculations of self-interest. In these relationships the principle of reciprocal obligations is implied (Aldrich \& Carter, 2004). In social situations in which people expect to deal with each other over an extended period, strongties yield many benefits, one of which is trust (Aldrich \& Carter, 2004). In South Africa, decreasing political confidence specifically on issues of transparency and accountability, correct appointments, affirmative action, crime, inflation, the widening income gap and corruption adversely affect trust. Such adverse environmental conditions influence the perceptions of entrepreneurs and often the result is that entrepreneurs and people with good ideas do not want to be involved with government departments or agencies unless they anticipate some corruptor or cronyist advantage (Klein, 2008; Von Broembsen, Wood \& Herrington, 2005).

Partial support was also found for Hypothesis 2, where differences were anticipated between Black, Indian and White groups on network assistance. Entrepreneurial networking relationships provide access to resources through social exchange, measured by the types of assistance provided by helpers. The usefulness of any relation is contextdependent. In the context of entrepreneurial networks,

TABLE 4: Ethnic group differences for attitudes towards in-group and out-group members.

\begin{tabular}{|c|c|c|c|c|c|c|c|c|c|}
\hline \multirow[t]{2}{*}{ Groups } & \multicolumn{2}{|c|}{ Black } & \multicolumn{2}{|c|}{ Asian } & \multicolumn{2}{|c|}{ White } & \multirow[t]{2}{*}{$\boldsymbol{F}$} & \multirow{2}{*}{$\begin{array}{c}\text { Sig. } \\
\text { (p-value) }\end{array}$} & \multirow{2}{*}{$\begin{array}{c}\text { Cohen's } \\
\text { d }\end{array}$} \\
\hline & $M$ & SD & $M$ & SD & $M$ & SD & & & \\
\hline \multicolumn{10}{|l|}{ Out-group } \\
\hline $\begin{array}{l}\text { I like to go to a party consisting mostly of } \\
\text { out-group members }\end{array}$ & 3.36 & 1.08 & 3.12 & 1.03 & 3.32 & 1.12 & 2.48 & 0.08 & 0.31 \\
\hline I like members of the out-group & 2.61 & 1.04 & 2.34 & 1.09 & 2.76 & 0.87 & 2.6 & 0.07 & 0.25 \\
\hline Members of the out-group are honest & 3.14 & 0.94 & 2.31 & 0.77 & 2.55 & 0.98 & 3.62 & 0.02 & 0.42 \\
\hline $\begin{array}{l}\text { Members of out-group are decent like } \\
\text { most members of the in-group }\end{array}$ & 2.68 & 1.04 & 3.11 & 1.09 & 3.25 & 1.12 & 2.75 & 0.06 & 0.28 \\
\hline \multicolumn{10}{|l|}{ In-group } \\
\hline I like members of the in-group & 2.08 & 0.97 & 3.87 & 0.54 & 3.99 & 0.43 & 2.39 & 0.09 & 0.34 \\
\hline Members of the in-group are honest & 2.74 & 0.90 & 3.55 & 1.05 & 3.41 & 0.97 & 2.17 & 0.11 & 0.12 \\
\hline Members of the in-group are decent & 2.45 & 0.86 & 2.99 & 0.73 & 3.01 & 1.29 & 3.4 & 0.03 & 0.45 \\
\hline Members of the in-group are friendly & 2.36 & 0.84 & 3.71 & 0.65 & 3.97 & 0.85 & 3.21 & 0.06 & 0.50 \\
\hline
\end{tabular}

Questions were measured on a 1-5 Likert scale where 1=strongly agree to $5=$ strongly disagree.

$M$, Mean; SD, Standard Deviation; $F$, Variable; $p$, probability; Sig., Significance. 
TABLE 5: ANOVA results for language groups.

\begin{tabular}{lccccc}
\hline Dependent variables & Sum of squares & $d f$ & Mean square & $\boldsymbol{F}$ & sig. \\
\hline In-group & & & & & \\
Between groups & 1.147 & 4 & 0.229 & 0.457 & 0.808 \\
Within groups & 87.368 & 174 & 0.502 & - & - \\
Total & $\mathbf{8 8 . 5 1 5}$ & $\mathbf{1 7 9}$ & - & - & - \\
Out-group & & & & & \\
Between groups & 6.256 & 4 & 1.251 & 3.954 & 0.002 \\
Within groups & 55.057 & 174 & 0.316 & - & - \\
Total & $\mathbf{6 1 . 3 1 2}$ & $\mathbf{1 7 9}$ & - & - & - \\
\hline
\end{tabular}

$d f$, degrees of freedom; $F$, Variable; sig., significance.

TABLE 6: Homogeneous Subsets for in-group across language groups.

\begin{tabular}{lccc}
\hline Tests & Home Language & $\boldsymbol{N}$ & $\begin{array}{c}\text { Subset for Alpha }=\mathbf{0 . 0 5} \\
\text { In-groups }\end{array}$ \\
\hline Scheffe ${ }^{\mathrm{a}, \mathrm{b}}$ & Sotho & 33 & 2.710 \\
& Other & 30 & 2.890 \\
& English & 12 & 2.909 \\
& Zulu & 49 & 2.925 \\
& Xhosa & 30 & 2.936 \\
Significance & Afrikaans & 26 & 2.907 \\
\hline
\end{tabular}

Means for groups in homogeneous subsets are displayed.

$N$, Number.

a, Uses harmonic mean sample size $=25.086$

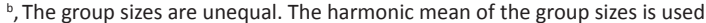

TABLE 7: Homogeneous Subsets for out-group across language groups.

\begin{tabular}{lcccc}
\hline Tests & Home Language & $N$ & \multicolumn{2}{c}{ Subset for Alpha $=\mathbf{0 . 0 5}$} \\
\cline { 4 - 5 } & & & Out-groups & In-groups \\
\hline Scheffe ${ }^{\mathrm{a}, \mathrm{b}}$ & Afrikaans & 12 & 3.604 & - \\
& Sotho & 30 & 3.890 & 3.890 \\
& English & 49 & 3.935 & 3.935 \\
& Xhosa & 26 & - & 4.142 \\
& Other & 33 & - & 4.190 \\
Significance & Zulu & 30 & - & 4.281 \\
\hline
\end{tabular}

Means for groups in homogeneous subsets are displayed.

$N$, Number.

a, Uses harmonic mean sample size $=25.086$

b The group sizes are unequal. The harmonic mean of the group sizes is used.

people need access to information and other resources (Aldrich \& Carter, 2004). Research on entrepreneurial networking has found that most business owners name no more than 2-3 helpers (Audretsch \& Keilbach, 2004), resonating with the present study findings. Considering that helpers were neither named nor was personal information asked; it is interesting that the only significant difference detected in terms of types of network assistance provided by helpers, was differences in relation to the Black ethnic group. A plausible explanation is that in South Africa assistance programmes have purposefully been set up by the government for Blacks as the dominant previously disadvantaged group. Perhaps the Asian and White groups rely more on conventional types of assistance as opposed to more widespread forms of assistance available to Black people.

For Hypothesis 3, no support was found for the hypothesised differences between groups in terms of network support relationships. This means that this sample of South African entrepreneurs, regardless of race appear to have similar support relationship structures. This finding is noteworthy because similar to the results obtained for this study, Mitchell and Co (2004) find that most networks members are either friends or family members; in other words, most of the contacts were met through the entrepreneur's own effort rather than through referrals. These results add support to the argument that a degree of homogeneity in networks exists, which is also in line with the interpersonal attraction theory (Byrne, 1971). It has been argued that people learn more from people like themselves than from other groups or experts (Flora \& Flora, 1993); communities tend to learn best from those that are at the same level as themselves. However, ties to more than one person with similar characteristics or in similar social locations are redundant and thus of questionable value in providing new information (Aldrich \& Carter, 2004).

Moreover, based on the relatively mediocre mean scores obtained for networking relationship support, across groups, it is postulated that in an emerging country context (such as South Africa), individuals form loosely structured networks without clear governance mechanisms to coordinate activities, pool resources, and pursue joint ventures. This means that networking is largely unstructured and coincidental in nature, where spouses or partners and/or friends or relatives are accessed as opposed to business associates or teachers or counsellors (Aldrich \& Carter, 2004).

In terms of Hypothesis 4, where differences were anticipated between Black, Indian and White groups in attitudes towards in-group and out-group members, few significant results were found. Only one item from the out-group category and one item from the in-group category had significant mean scores. In accounting for these results it seems that ethnicity, when defined as self-identification with a particular ethnic group (in-group) or a label imposed by outsiders (out-group), seems not to be a differentiating variable in determining in-group and out-group attitudes. Moreover, practical significance in terms of these results could not be detected.

By focusing on in-group and out-groups, the present study has improved understanding of how group perceptions may explain attitudes towards different racioethnic groups, which are usually driven by social identities and these are typically evaluated in a particular intergroup context (Bhowon \& Tseung-Wong, 2003). A study on intergroup stereotypes extends a model of intergroup perception by focusing on how perceivers differentiate amongst particular immigrant groups, specified by nationality, race, ethnicity, and class (Lee \& Fiske, 2006). Based on the present study's results and similar studies, it seems that racial or ethnic identity is no doubt a complex construct that includes measures of ethnicity-related practices, one's subjective self-labelling and one's ascribed ethnicity (Bornman, 2006; Zagefka, 2009).

Comparisons between language groups in terms of in-group and out-group analysis formed the basis of Hypothesis 5 . The findings indicate no significant differences on scores across languages for this in-group and out-group analysis. 
In this particular case, this result is in line with all the other hypotheses in that language seems not to be a differentiating variable in determining in-group and out-group attitudes. Using this socio-cultural variable, language and determining inclusion or exclusion (who is considered part of the in-group and part of the out-group) does not necessarily seem to be a determinant in providing a basis for difference amongst this group of entrepreneurs.

Resonating with similar studies, the present findings reveal that, ethnicity, defined as self-identification with a particular ethnic group (in-group), or a label imposed by outsiders (out-group), is not totally insignificant; instead it is a possible outcome of the patterns by which in-group and out-group interactions are structured. By focusing in-group and outgroups, the present study has improved understanding of how group perceptions may explain the effect of different entrepreneurial networking practices in ethnic groups.

Integrating this study's empirical results with established literature, it seems that ethnicity is not simply a matter of belonging to certain cultural grouping. Members of ethnic groups vary both in strength of ethnic identification and the degree of acculturation (Aldrich \& Waldinger, 1990; Chaganti \& Greene, 2002; Hackett et al., 1992). This discussion on ingroup and out-group analysis can also be read in conjunction with the societal legitimisation perspective which has been invoked to explain how entrepreneurial activity may increase when societal or cultural values are supportive towards new venture creation (Davidsson \& Wiklund, 1997). As a matter of fact, it has been suggested that entrepreneurship is a self-reinforcing process. Bygrave and Minniti (2000) propose that an agent's choice is influenced by others' chosen paths. Entrepreneurship leads to more entrepreneurship and the degree of entrepreneurial activities is an outcome of a dynamic process in which social habits (entrepreneurial memory) are as important as legal and economic factors. Thus entrepreneurs act as catalysts of economic activity, where the entrepreneurial history of a community is important (Bygrave \& Minniti, 2000). The present study's results are also interesting in the broader context of entrepreneurship as a universal phenomenon, that is, does an entrepreneurial archetype exist (Thomas \& Mueller, 2000) versus those who emphasise the importance of cultural divergence (Dodd \& Patra, 2002). Research by McGarth and MacMillan (1992), pertaining to the dilemma whether entrepreneurs across various cultures are more similar to each other than to counterparts in their own countries, finds that entrepreneurs share a predictable set of values different from non-entrepreneurs. These authors stress that out-group beliefs and deviant behaviour sometimes transcend cultures. Similarly, McGarth, MacMillan and Scheinberg (1992) found a reasonable degree of support for the idea that entrepreneurs share a predictable set of values, when compared with nonentrepreneurs. Practically such arguments suggest that crosscultural or ethnic differences may not be as pronounced as previously thought and similarities across cultures may in fact be driving globalisation. This line of reasoning concurs with Levitt's (1983) premise that world markets are being driven toward a converging commonality.

\section{Implications and recommendations}

Investigating how and why the prevailing social, historical, political and ideological system and norms in contemporary society foster or inhibit the spirit of entrepreneurship amongst particular societal groups, is advocated as a meaningful pursuit (Ogbor, 2000, Urban, 2006, 2007). If entrepreneurship is not valued in the community or culture of a particular country, then not only will it be associated with criminality and corruption but also other forms of economic encouragement will prove ineffective (Baumol, 1990).

Implications of the study suggest that although many studies point towards a universal entrepreneurship culture (Shenkar, 2001), various criticism of scientific positivism has led to the rejection of many of its major tenants, which includes the notion of universality. It has been argued that empirical social theory does not address cultural and interpersonal differences, which has the effect of typical normative theory, that is, to devalue differences. In particular the assumption of universality is questioned on many grounds in that it is neither culturally sensitive nor does it sufficiently appreciate historical specificity. In many cases the universality assumption has led to de-contextualised truth and ethnocentrism (Cavusgil \& Das, 1997).

The uncritical adoption of western concepts is often not helpful in an ethnically diverse context such as South Africa. On this point it is recommended that researchers move beyond ethnocentric approaches, which assume entrepreneurship is similar in different cultures, and undertake comparative studies that look for both similarities and differences (Aycan, Kanungo, Mendonca, Yu, Deller, Stahl \& Kurshid, 2000), as this study has shown.

The practical value of the present study points to several areas of interest to entrepreneurs, policy makers and educators; through demonstrating the multifaceted nature of entrepreneurial networks for different groups and their explanatory potential in understanding entrepreneurship, focus areas in networking can be identified and fostered to increase entrepreneurship outcomes. The present study indicates that entrepreneurial networking is largely independent of ethnic group composition. This implies that networking practices are integrated across different ethnic groups and a more holistic view of networking can be taken. Training entrepreneurs to be aware of the multiple influencing factors in networking will raise their level of sophistication and ability to correctly gauge opportunities. Entrepreneurs, educators, and consultants all benefit from better understanding of how networking practices are more similar rather than different amongst South African racial groups.

\section{Limitations and future research}

In addressing limitations of present and similar research, it is concluded that most of the literature dealing with minority entrepreneurship approaches the topic from a descriptive 
perspective, which causes variation in conceptualisation of minority groups, unity of analysis, and theoretical disciplines (Basu \& Altinay, 2002). These differences create confusion and do not allow for meaningful comparisons of ethnic related studies. The point was made earlier in the article that the widely used term ethnic minority does not fit the complex multi-ethnic nature of South African society. More detailed, comparative data on multiple groups, with comparable information collected on each group is a possible remedy. Another limitation of this article is that a crosssectional study loses its dynamic aspects of entrepreneurial networking. A relatively static picture of network positions was surveyed. By investigating the dynamics of networking processes in a temporal framework, Jack, Dodd \& Anderson (2008) demonstrate that networks are vital living organisms, changing, growing and developing over time.

\section{Conclusion}

This article has contributed to the research literature on social network and provides a discussion on the interface between entrepreneurship and networking practices. By recognising the importance of group composition in order to understand entrepreneurial networking in a multicultural context, the findings indicate that entrepreneurial networking is largely independent of ethnic group composition. Empirical evidence reveals that entrepreneurs utilise similar support structures and that a degree of homogeneity is evident in networking ties across ethnic groups.

\section{References}

Adler, P.S., \& Kwon, S.W. (2002). Social capital: prospects for a new concept. Academy of Management Review, 27(1), 17-40. doi:10.2307/4134367

Ahwireng-Obeng, F. (2006). Entrepreneurship in Africa. In J. Luiz (Ed). Managing Business in Africa. Practical Management Theory for an Emerging Market, (pp. 188-209). South Africa: Oxford University Press.

Aldrich, H.E., \& Carter, M.N. (2004). Social networks. In W.B. Gartner, K.G. Shaver, N.M. Carter \& P.D. Reynolds (Eds). Handbook of Entrepreneurial Dynamics. The Process of Business Creation, (pp. 324-335). California: Sage Publications.

Aldrich, H.E., \& Waldinger, R. (1990). Ethnicity and entrepreneurship. Annual Review of Sociology, 16, 111-135. doi:10.1146/annurev.so.16.080190.000551

Aldrich, H.E. \& Zimmer, C. (1986). Entrepreneurship through social networks. In S. Similor \& D. Sexton (Eds). The Art and Science of Entrepreneurship, (pp. 324-335). New York: Ballinger.

Arenius, P., \& De Clercq, A. (2005). A network based approach on opportunity recognition. Small Business Economics, 24, 249-265. doi:10.1007/s11187-0051988-6

Audretsch, D.B., \& Keilbach, M. (2004). Entrepreneurship capital and economic performance. Regional Studies, 38(8), 949-959. doi:10.1080/0034340042000280956

Autio, E. (2007). Report on High-Growth Entrepreneurship: Global Entrepreneurship Monitor Report. Babson College and London Business School.

Aycan, Z., Kanungo, R.N., Mendonca, M., Yu, K., Deller, J., Stahl, G., \& Kurshid, A. (2000). Impact of culture on human resource management practices: A 10-county comparison. Applied Psychology, 49(1), 192-222. doi:10.1111/1464-0597.00010

Basu, A., \& Altinay, E. (2002). The interaction between culture and entrepreneurship in London's immigrant businesses. International Small Business Journal, 20(4), 371-393. doi:10.1177/0266242602204001

Baumol, W.J. (1990). Entrepreneurship: productive, unproductive and destructive. Journal of Political Economy, 98(5), 893-921. doi:10.1086/261712

Birley, S., Cromie, S., \& Myers, A. (1991). Entrepreneurial networks: their emergence in Ireland and overseas. International Small Business Journal, 9, 56-73. doi:10.1177/026624269100900404

Bhowon, U., \& Tseung-Wong, C.N.G. (2003). Group identification as a multidimensional construct: the case of ethnicity. Ife Psychologia, 1, 86-98.

Blundel, R., \& Smith, D. (2001).Business Network Report: Research Report to the Small Business Service. Retrieved September 18, 2008, from http://www.sbs.gov. uk/SBS_Gov_files/researchand stats.pdf
Bond, M.H., \& Smith.P.B. (1996). Cross-Cultural social and organizational psychology. Annual Review of Psychology 47, 205-235. doi:10.1146/annurev.psych.47.1.205, PMid:15012481

Bornman, E. (1999). Self-Image and ethnic identification in South Africa. Journal of Social Psychology, 139(4), 1-13. doi:10.1080/00224549909598401, PMid:10457758

Bornman, E. (2006). National symbols and nation-building in the post-apartheid South Africa. International Journal of Intercultural Relations, 30, 383-399. doi:10.1016/j.ijintrel.2005.09.005

Bureau of Market Research. (2001). Research Report. No. 285. Pretoria: UNISA

Bygrave, W.D., \& Minniti, M. (2000). The social dynamics of entrepreneurship. Entrepreneurship Theory and Practice, 24(3), 25-36.

Byrne, D. (1971). The attraction paradigm. New York: Academic Press.

Carmichael, T., \& Rijamampianina, R. (2006). Managing Diversity in Africa. In J. Luiz (Ed.). Managing Business in Africa. Practical Management Theory for an Emerging Market, (pp. 161-187). South Africa: Oxford University Press.

Carter, N.M., Reynolds, P.D., \& Gartner, W.B. (2004). Perceptions of entrepreneurial climate. In W.B. Gartner, K.G. Shaver, N.M. Carter \& P.D. Reynolds (Eds.).
Handbook of Entrepreneurial Dynamics, (pp. 412-429). The Process of Business Handbook of Entrepreneurial Dynamics,
Creation. California: Sage Publications.

Carson, D., Cromie, S., McGowan, P., \& Hill, J. (1995). Marketing and entrepreneurship in SMEs. Englewood Cliffs, NJ: Prentice-Hall.

Cavusgil, S.T., \& Das, A. (1997). Methodological issues in empirical cross cultural research: a survey of the management literature and a framework. Management International Review, 37, 71-96.

Chaganti, R., \& Greene, P.G. (2002). Who are ethnic entrepreneurs? A study of entrepreneurs' ethnic involvement and business characteristics. Journal of Small Business Management, 40(12), 126-144. doi:10.1111/1540-627X.00045

Chan, Y.E., Bhargava, N., \& Street, C.T. (2006). Having arrived: the homogeneity of high-growth small firms. Journal of Small Business Management, 44(3), $426-440$.

Cohen J. (1988). Statistical power analysis for behavioural sciences. (2nd edn.). Hillside, NJ: Erlbaum.

Cooper, R.C., \& Denner, J. (1998). Theories linking culture and psychology: universal and community specific processes. Annual Review of Psychology, 49, 559-84. doi:10.1146/annurev.psych.49.1.559, PMid:15012474

Curran, J., Jarvis, R., Blackburn, R.A., \& Black, S. (1993) .Networks and small firms: constructs, methodological strategies and some findings. International Small Business Journal, 11(2), 13-25. doi:10.1177/026624269301100202

Davidsson, P. (2004). Researching entrepreneurship, International Studies in Entrepreneurship. New York: Springer. doi:10.1016/S0883-9026(02)00097-6

Davidsson, P., \& Honig, B. (2003). The role of social and human capital among nascent entrepreneurs. Journal of Business Venturing, 18, 301-331. doi:10.1016/S0167-4870(97)00004-4

Davidsson, P., \& Wiklund, J. (1997). Values, beliefs and regional variations in new firm formation rates. Journal of Economic Psychology, 18, 179-199.

De Klerk, S. (2010). The importance of networking as a management skill. South African Journal of Business Management, 41, 37-49.

Dodd, S.D. (1997). Social network membership and activity rates: some comparative data. International Small Business Journal, 15(4), 80-87. doi:10.1177/0266242697154005

Dodd, S.D., \& Patra, E. (2002). National differences in entrepreneurial activity. Entrepreneurship and Regional Development, 14, 117-134. doi:10.1080/08985620110111304

Duncan, N. (2003). Race talk: discourses on race and racial difference. International Journal of Intercultural Relations, 27, 135-156. doi:10.1016/S01471767(02)00095-0

Eghosa, E., \& Osaghae, O. (2005). Civil society and ethnicity in Africa. Politeia, 24(1), 64-84.

Flint, K. (2006). Indian-African encounters: polyculturalism and African therapeutics in Natal, South Africa, 1886-1950s. Journal of Southern African Studies, 32(2), 367-385.

Flora, C., \& Flora, J. (1993). Entrepreneurial social infrastructure: a necessary ingredient. Annals, 529

Foxcroft, C.D., \& Roodt, G. (2001). An introduction to psychological assessment in South African context. Johannesburg: Oxford University Press.

Foxcroft, M., Wood, E., Kew, J., Herrington, M., \& Segal, N. (2002). South African Global Entrepreneurship Monitor Executive Report. Cape Town: Graduate School of Business.

Franchi, V., \& Swart, T.M. (2003). From apartheid to affirmative action: the use of 'racial' markers in past, present and future articulations of identity among South African students. International Journal of Intercultural Relations, 27, 209-236. doi:10.1016/S0147-1767(02)00093-7

Gartner, W.B., Shaver, K.G., Carter, N.M., \& Reynolds, P.D. (2004). Handbook of entrepreneurial dynamics: the process of business creation. (Eds.). Thousand Oaks, CA: Sage Publications.

Gong, L. (2007). Ethnic identity and identification with majority group: relations with national identity and self-esteem. International Journal of Intercultural Relations, 31, 503-523. doi:10.1016/j.ijintrel.2007.03.002 
Granovetter, M. (1973). The strength of weak ties. American Journal of Sociology, 78 1360-1380. doi:10.1086/225469

Granovetter, M.S. (1985). Economic action and social structure: The problem with embeddedness. American Journal of Sociology, 91, 481-510. doi:10.1086/228311

Greve, A., \& Salaff, J.W. (2003).Social networks and entrepreneurship. Entrepreneurship Theory and Practice, Fall, 1-22. doi:10.1111/1540-8520.00029

Griffiths, J.A., \& Nesdale, D. (2006). In-group and out-group attitudes of ethnic majority and minority children. International Journal of Intercultural Relations, 30, 735-749 doi:10.1016/j.ijintrel.2006.05.001

Hackett, G., Betz, N., Casas, J., \& Rocha-Sinjh, I. (1992). Gender, ethnicity and socia cognitive factors predicting achievement. Journal of Counselling Psychology, 39 527-538. doi:10.1037/0022-0167.39.4.527

Herrington, M., Kew, J., \& Kew, P. (2010). Tracking entrepreneurship in South Africa: a GEM perspective. Cape Town: Graduate School of Business.

Hofstede, G. (1991). Cultures and organizations. Software of the mind. London: McGraw-Hill.

Jack, S.L., \& Anderson, A.R. (2002). The effects of embeddedness on the entrepreneurial process. Journal of Business Venturing, 17, 467-487. doi:10.1016/ S0883-9026(01)00076-3

Jack, S., Dodd, S.D., \& Anderson, A.R. (2008). Change and development of entrepreneurial networks over time: a processual perspective. Entrepreneurship and Regional Development, 20(2), 125-159. doi:10.1080/08985620701645027

Jackson, J.W. (2002). Inter-Group attitudes as a function of different dimensions of group identification and perceived inter-group conflict. Self and Identity, 1, 11-33. doi:10.1080/152988602317232777

Jackson, J.W., \& Smith, E.R. (1999). Conceptualizing social identity: a new framework and evidence for the impact of different dimensions. Personality and Social Bulletin, 25, 120-135. doi:10.1177/0146167299025001010

Jansen, J.D. (2004). How mergers shape the institutional curriculum. Education as Change, 7, 3-19.

Klein, M. (2008). Government not doing a Good Job, Sunday Times, 20 January, p. 3.

Kruger, T., \& Roodt, G. (2003). Hofstede's VSM-94 revisited: Is it reliable and valid? South African Journal of Industrial Psychology, 29, 75-82.

La Porta, R., \& Schleifer, A. (2008). The unofficial economy and economic development. National Bureau of Economic research, working paper No. 14520. Massachusetts: National Bureau of Economic Research.

Lee, T.L., \& Fiske, S.T. (2006). Not an out-group, not yet an in-group: Immigrants in the Stereotype Content Model. International Journal of Intercultural Relations, the Stereotype Content Model. International Journ

Lenartowicz, T., \& Roth, K. (2001). Does subculture within a country matter? A cross cultural study of motivational domains and business performance in Brazil. Journal of International Business Studies, 32, 22-35. doi:10.1057/palgrave.jibs.8490954

Levitt, T. (1983). The globalization of markets. Harvard Business Review, May-June, pp. 7-14.

Lopez-Claros, A., Altinger, L., Blanke, J., Drezniek, M., \& Mia, I. (2006). The global competitiveness index: identifying the key elements of sustainable growth. Global Competitiveness Report, 2006-2007, (pp. 3-50). Retrieved on 21 April 2008, from http://www.weforum.org/en/intiatives/gcp

Low, M., \& Macmillan, I. (1998). Entrepreneurship: past research and future challenges. Journal of Management, 14, 139-161. doi:10.1177/014920638801400202

Maas, G., \& Herrington, M. (2007).Global Entrepreneurship Monitor. South African Report. South Africa. Cape Town: Graduate School of Business.

McDade, B.E., \& Spring, A. (2005). The 'new generation of African entrepreneurs' networking to change the climate for business and private sector-led development. Entrepreneurship and Regional Development, 17, 17-42. dovelopment. Entrepreneurship and

McGrath, R.G., \& Macmillan, I.C. (1992). More like each other than anyone else? A cross-cultural study of entrepreneurial perceptions. Journal of Business Venturing 7, 419-429. doi:10.1016/0883-9026(92)90017-L

McGrath, R.G., Macmillan, I.C., \& Scheinberg, S. (1992). Elitists, risk takers, and rugged individualists? An exploratory analysis of cultural differences between entrepreneurs and non entrepreneurs. Journal of Business Venturing, 7, 115-135. doi:10.1016/0883-9026(92)90008-F

McMillan, J., \& Woodruff, C. (2002). The central role of entrepreneurs in transition economies. Journal of Economic Perspectives, 16(3), 153-170. doi:10.1257/089533002760278767

Menzies, T.V., Filion, L.J., Brenner, G.A., \& Elgie, S. (2007). Measuring ethnic involvement: development and initial testing of an index. Journal of Small Business Management, 45(2), 267-282.

Miller, N.J., Besser, T., \& Malshe, A. (2007). Strategic networking among small businesses in small US communities. International Small Business Journal, 25(6), 631-666. doi:10.1177/0266242607082525

Mitchell, B.C., \& Co, M.J. (2004). Entrepreneurial networks: findings from a South African study. South African Journal of Economic and Management Sciences, 7(4), 589-600.
Naude, W.A., \& Havenga, J.J.D. (2007). An overview of African entrepreneurship and small business research. In L.P. Dana \& R.B. Anderson (Eds). International handbook of research on indigenous entrepreneurship, (pp. 28-46). United Kingdom: Edward Elgar.

Nkosi, T.J., \& Roodt, G. (2004). An assessment of bias and fairness of the culture assessment instrument. South African Journal of Human Resource Management 2, 24-36.

Nunnally, J.C. (1978). Psychometric theory. (2nd edn.). New York: McGraw-Hill.

Ogbor, J.O. (2000). Mythicizing and reification in entrepreneurial discourse: ideologycritique of entrepreneurial studies, Journal of Management Studies, 37(5), 605635. doi:10.1111/1467-6486.00196

Orford, J., Herrington, M., \& Wood, E. (2004). South African Report, Global Entrepreneurship Monitor South Africa. Cape Town: Graduate School of Business.

Pallant, J. (2007). SPSS. (3rd edn.). New York: McGraw-Hill Open University Press.

Putnam, R. (1995). Turning in, turning out: the strange disappearance of social capital in America. Political Science and Politics, 28, 664-683. doi:10.2307/420517

Ramachandran, V., \& Shah, M. J. (1999). Minority entrepreneurs and private sector growth in Sub-Saharan Africa. The World Bank. Discussion paper, No. 086.

Sawyer, O.O., McGee, J., \& Peterson, M. (2003).Perceived uncertainty and firm performance in SMEs. International Small Business Journal, 21(3), 269-290. doi:10.1177/02662426030213002

Schumpeter, J.A. (1934). The theory of economic development. Cambridge: Harvard University Press.

Seda. (2007). Review of trends on entrepreneurship and the contribution of small enterprises to the economy of South Africa, 2000-2006. Johannesburg: South African Enterprise Development Agency.

Shenkar, O. (2001). Cultural distance revisited: towards a more rigorous conceptualization and measurement of cultural differences. Journal of International Business Studies, 32, 4-16. doi:10.1057/palgrave.jibs.8490982

Simmel, G. (1955). Conflict and the web of group-affiliations. New York: The Free Press.

Slotte-Kock, S., \& Coviello, N. (2010). Entrepreneurship research on network processes: a review and ways forward. Entrepreneurship Theory and Practice, Jan, 31-57. doi:10.1111/j.1540-6520.2009.00311.x

South Africa Business Guidebook. (2005/2006). Your essential a-z business resources with an investment focus. (9th edn.). South Africa: Write Stuff Publishing.

South Africa Survey. (2007). Survey results 2006-2007. In J. Kane-Berman (Ed.). South African Institute of Race Relations, (pp. 46-59). Johannesburg, South Africa: SAIRR.

Steensma, K.H., Marino, L., \& Weaver, M.K. (2000). Attitudes toward cooperative strategies: a cross cultural analysis of entrepreneurs. Journal of International Business Studies, 31(4), 591-610. doi:10.1057/palgrave.jibs.8490924

Stephan, C.W., \& Stephan, W.G. (2000). The measurement of racial and ethnic identity. International Journal of Intercultural Relations, 24, 541-552. doi:10.1016/S01471767(00)00016-X

Stevens, G. (2003). Academic representations of 'race' and racism in psychology: Knowledge production, historical context and dialectics in transitional South Africa. International Journal of Intercultural Relations, 27, 189-207.

Street, C.T., \& Cameron, A.F. (2007). External relationships and small business: review of small business alliance and network research. Journal of Small Business Management, 45(2), 239-266.

Thomas, A.S., \& Mueller, S.L. (2000). A Case for comparative entrepreneurship: assessing the relevance of culture. Journal of International Business Studies, 31 14-27. doi:10.1057/palgrave.jibs.8490906

Urban, B. (2006). Entrepreneurial self-efficacy in a multicultural society: measures and differences. South African Journal of Industrial Psychology, 32(1), 2-10.

Urban, B. (2007). A framework for understanding the role of culture in entrepreneurship. Acta Commercii, 7, 82-95.

Von Broembsen, M., Wood, E., \& Herrington, M. (2005). Global Entrepreneurship Monitor, South African Report. Graduate School of Business: University of Cape Town.

Watson, W.E., \& Kumar, K. (1992). Differences in decision making regarding risk taking: a comparison of culturally diverse and culturally homogeneous groups. International Journal of Intercultural Relations, 16, 53-65. doi:10.1016/0147 1767(92)90005-F

Weber, M. (1948). Essays in sociology. Transl. and edited by H.H. Gerth \& C. Wright Mills. London: Routledge.

Welter, F., \& Smallbone, D. (2006). Exploring the role of trust in entrepreneurial activity. Entrepreneurship Theory and Practice, 30(4), 465-476. doi:10.1111/ j.1540-6520.2006.00130.x

World Economic Forum. (2006). Global Competitiveness Report 2006/7. Retrieved April 21, 2007, from http://www.weforum.org/en/initiatives/gcp.html

Zagefka, H. (2009). The concept of ethnicity in social psychological research Definitional issues. International Journal of Intercultural Relations, 33, 228-241. doi:10.1016/j.ijintrel.2008.08.001 